\title{
Students' Problems in Transactional Speaking on English Foreign Learners (EFL) FKIP Nommensen Pematangsiantar
}

\author{
Bernieke Anggita Ristia Damanik
}

English Department Faculty Teacher Training and Education, Nommensen University Pematangsiantar, Indonesia. berniekedamanik2016@gmail.com

\begin{abstract}
This research is a study on the Students Problems in Transactional Speaking on English Foreign Learners (EFL) FKIP Nommensen Pematangsiantar. In this research, the problem is "What are the students' problems in vocabulary when they are speaking English?"To answer the problem of the study the writer follow some theories namely Nunan (1991) which concern with definition of speaking and the elements of speaking, Brown (2001) which concern with types of speaking performance, Richards (2008) which concern the functions of speaking, Ur (1996) which concern with some difficulties in speaking, Thornburry (2005) which concern with classroom speaking activities and Keegen (2009) which concern with descriptive qualitative research. The methodology which is used in this study is qualitative research, which purposes to find out the result of this research. This subject of the study is the students transactional speaking the second semester academic year 2017. The object of the study is the students problems in vocabulary when they are speaking English. To collect the data, the writer use test as instrument by asks the students to practice promoting product. The data analysis shows that most of the students face problems in vocabulary namely the choice of word inaccurate, the arrangement of word is wrong and limitations of vocabulary. Finally the writer concludes that the students have problems in speaking English. The students face some problems in vocabulary namely the choice of word inaccurate, the arrangement of word is wrong and limitations of vocabulary. The writer hopes that this research can be useful for the readers.
\end{abstract}

Keywords-Problem, Transactional Speaking.

\section{INTRODUCTION}

Talking about language, students in language are one of the instruments of the people for communication. It is taught to the students in order to communicate. They are taught language as a means to express human taught. We use language to inform the people around us of what we feel, what we desire, and question/understand the world around us. We communicate effectively with our words, gestures, and tone of voice in a multitude of situation. The writer defined that is one way to express something, and make interaction, and also making communication between the people. The students doing activities that involve real communication, carrying out meaningful tasks, and using language which is meaningful to the learner promote learning.

They key terms used in this research are as follows:

1. Problems : difficulties that students pass in speaking, such as they have no confident, they lack of vocabulary, they difficult speak with grammaticaly right, they use mother tongue, and they can not pronounce the words correctly.

2. Speaking : a way to communicate, share idea or opinion, and the way to express the feeling but most of the students had low ability in speaking.

1. The Problem of Research

Based on what has been described in the background of the study, the writer formulates the problem as follow: "What are the students problems in Transactional Speaking On English Foreign Learners (EFL) FKIP Nommensen Pematangsiantar?"

\section{The Objective of Research}

In reference to the problem that have been shown, this research is intended to find out Students' Problems in Transactional Speaking On English Foreign Learners (EFL) FKIP Nommensen Pematangsiantar.

\section{The Significances of Research}

The finding of this research is significance as theoritically and practically. As theoritically this research is usefull for the researcher to know the students problems in vocabulary when they speaking english. As practically is useful to inform the teacher about the students problems in speaking english that need to be given emphasis to assist students in speaking english well.

\section{REVIEW OF RELATED LITERATURE}

\section{Definitions of Speaking}

According to Nunan (1991: 47), speaking is one of four skills of English. It can help people to understand 
something from other interlocutors of language. Speaking will be focus for the first section on speaking. It involves fluent and accuracy expression meaning, the exercising of pragmatic, or communicative, competence and the observance of the rules of appropriate. Communication is a collaboration venture in which the interlocutors negotiate meaning in order to achieve their communication. Brown (2001: 267) stated that when someone can speak a language it means that he can carry on a conversation reasonably competently. In addition, he states that the benchmark of successful acquisition of language is almost always the demonstration of an ability to accomplish pragmatic goals through an interactive discourse with other language speakers.

\section{Elements of Speaking}

Language use in such a situation is primarily message oriented. It is important that the recipient gets the informative detail correct when they are speaking. Nunan (1991) there are five components of language that influence speaking ability. The ability in speaking English is not only seen how fast they are speaking but they are pay attention to the elements or characteristic a good speaking. There are five elements in speaking :

\section{a. Pronunciation}

In pronunciation, the students are emphasized to master the vowels, consonants, stress and also intonation. If the students want to be able to speak english fluently, they have to understand how to pronounce them. If the speaker has good pronunciation so the listener will be easy to understand what the speaker says so that the communication can be understood clearly. They must be able to articulate the words and create the physical sounds that carry meaning.

At the level of word pronunciation, foreign language learners regularly have problems distinguishing between sounds in the new language that do not exist in languages they already know. English words can be difficult to pronounce and when speaking English, you have to consider not only the pronunciation of the individual words, but also the connection between the words in the sentence. There's also the "rhythm" and intonation of the sentence to consider and sometimes your mouth gets confused.

\section{b. Grammar}

It is obvious that in order to be able to speak foreign language, it is necessary to know a certain amount of grammar and vocabulary. Grammar is the basic unit of meaning such as words, phrases, clause, and sentence. Therefore, grammar is very important in speaking because if the teacher doesn't master grammar structure, he could not speak English well. To form a good communication, the speaker must master the structure in the sentence about what he wants to say so that the listener can understand it. English always deals with reference of time while Indonesian does not have one. Moreover, there are singular and plural forms that the students have to distinguish and still many forms that have to be learned. Most students are very easy to get confused with English grammar, while grammar is very needed to form a right sentence. If the students do not have grammar mastery, of course they will not be able to produce sentences that grammatically right. Realizing that the grammar students have is very weak, so they feel shy when they want to produce English sentences orally.

\section{c. Vocabulary}

According to Ur (1996), vocabulary refers to words that are taught in foreign language. It means that those words do not come from the students' native language. They come from foreign language being learned, in this case English. The writer concludes that vocabulary is a list or set of words with their meanings for certain foreign language which is being taught and learned. To speak in a foreign language learners must master the sound system of the language, have almost instant access to appropriate vocabulary and be able to put words together intelligibly with minimal hesitation. In addition, they must also understand what is being said to them, and be able to respond appropriately to maintain in amicable relations or to achieve their communicative goals. Because speaking is done in real-time, learners' abilities to plan, process and produce the foreign language are taxed greatly. The range, precision, and the usage of vocabulary features in a conversation used by test takers indicate the level of how proficient they are. While according to Hughes (2003:131), proficiency description of vocabulary when speaking english, the choice of words sometimes inaccurate, limitations of vocabulary, and the arrangement of word is wrong cause not appropriate to the topic. The choice of word is simply usage of the best words for getting the point across or the manner in which something is expressed in words. If the choice of word inaccurate it's a misunderstanding of the meaning of a word that cause the word inappropriate to the topic, difficult to interpret and understand the meaning. Lack implies that there is none there to start with, but sometimes missing something. Vocabulary is the important thing in using language. It can be defined as single words, phrases and also idioms. It is clear that limited vocabulary mastery makes conversation virtually impossible. Sometimes when speaking English, there is a sentence in mind, but missing two or three important vocabulary words and then it becomes difficult to say what our thinking. So the speaker must memorize as many as he/she can in order to create a good communication. A sentence is a collection of words that convey sense or meaning. If the words in a sentence are arranged wrong the meaning of the sentence 
certainly cannot understand. The arrangement of word wrong cause difficult to interpret and understand the meaning even the sentence has error meaning

\section{d. Fluency}

Fluency is the ability to talk freely without too much stopping or doubting in speaking. In speaking, we must speak fluency because listeners are able to response what we say. It is about the ease and speed of the flow of speech. A person tries to speak or to say the utterances based on some aspects. People have to be aware in deciding the word stressed or unstressed. The stress influenced by the words syllable. In English, in normal style, there are some words that have no stress like pronoun, number, article, etc. But there are some word that have stress such as : verb, noun, adjective, or adverb. If a person is correct to decide the stress position in the sentences will have good fluency.

\section{d. Comprehension}

The last element in speaking is comprehension. Comprehension is discussed by both speakers because comprehension can make people getting the information what they want. Comprehension can be defined as the ability to understand about the meanings what the speaker says. So, if the students want to get something from the speaker, they have to be able to do comprehension about it.

\section{RESEARCH METHODOLOGY}

\section{The Design of Research}

This research is a descriptive qualitative research. As Keegan (2009:11) states "Qualitative research explores questions such as what, why and how, rather than how many or how much, it is primarily concerned with meaning rather than measuring". This research is to find out what are the students problems on vocabulary in Transactional Speaking On English Foreign Learners (EFL) FKIP Nommensen Pematangsiantar"

\section{The Subject of Research}

The subject of this research is students English Foreign Learners (EFL) FKIP Nommensen Pematangsiantar on Transactional Speaking Classs at the second semester, the first year.

\section{The Object of Research}

The object of this research is the students' problems on vocabulary in Transactional Speaking On English Foreign Learners (EFL) FKIP Nommensen Pematangsiantar". The problems that are researched by the researcher are viewed from elements of speaking focuses on vocabulary.

\section{The Instrument of Research}

In a research, instrument is a tool for collecting data. It plays a very significant role in that it greatly determines the result of the study. The writer uses test as an instrument of the research. The test is oral test. The writer asks the students to promote a product in front of the class one by one.

\section{FINDINGS AND DISCUSSION}

\section{Research Findings}

The writer finding during the research that most of the students of English Foreign Learners (EFL) FKIP Nommensen Pematangsiantar in transactional speaking class have problems in speaking English especially on their vocabulary. The students face some problems in using vocabulary when they are speaking English namely the choice of word is not accurate, the arrangement of word is wrong and the limitations of vocabulary. Most of the students when they are speaking English the word that used is not accurate so that not appropriate to the topic.The writer also finds most of the students when they are speaking English can not arrange the word correctly so that cause difficult to interpret and understand the meaning. And when they are speaking English they use indonesian language because they limits in vocabulary.

\section{Discussion}

Based on the research finding, the writer interprets that most of the students of English Foreign Learners (EFL) FKIP Nommensen Pematangsiantar in transactional speaking class have problems in speaking English. Most of the students face some problems in vocabulary when they are speaking English namely the choice of word is not accurate, the arrangement of word is wrong and the limitations of vocabulary. Most of the students cannot arrange word and sometimes the choice of the word that used is not accurate. The students also limits in vocabulary because most of them when they are speaking English, they use indonesian language. The students problems in vocabulary when they are speaking make their presentation not good enough. They need to know more vocabulary so that they can speak in english totally and can able to choose the accurate word that appropriate to the topic. By trying to speak english to their friends or teacher can improve their speaking skill and add their vocabulary.

\section{CONCLUSION}

Based on the research findings the writer concludes what the students problems in using vocabulary when they speak English. Most of the students of English Foreign Learners (EFL) FKIP Nommensen Pematangsiantar in transactional speaking class have problems in speaking English especially on their vocabulary. They face some problems in using vocabulary when they speak English namely choosing the correct choice of word, arranging of word in the sentence and limitation of vocabulary. Most of students when they speak English the choice of word is not accurate. If the choice of word is not accurate it is 
misunderstanding of the meaning of the word that makes not appropriate to the topic they talk about. Most of the students when they speak English, the arrangement of word is wrong. If the sentences are arranged wrong that makes difficult to interpret and understand the meaning even the sentence has error meaning. And most of the students limits in their vocabulary. Sometimes when they speak English, there is a sentence in their mindbut missing two or three important words and difficult to say what they want to say so they use indonesian language. From the conclusion above, the writer give a contibution towards to the problems the students faced in using vocabulary when they speak English. The students have to try to speak English in daily activities even in the school or out of the school so it can improve their ability in speaking English.

1. Some students got stuck to say what they want to say. Students don't know how to express their idea by using English. There are many words in their mind but they lost the word when they try to speak the language they only give a short answer like yes or no even when they feel agree, disagree or even want to suggest someone.

2. Most of the students are too shy and afraid to take a part in the conversation. Most of the students are still clumsy in speaking, they just speak when the teacher ask them.

3. The cause of the weak value of speaking students.

4. The lack of attractiveness of the students in learning English

5. The students who are lack of vocabulary

6. Some students did not give positive response

\section{REFERENCES}

[1] Brown, Douglas H. D.2001. Teaching by Principles: An Interactive Approach toLanguage Pedagogy Second Edition. San Fransisco : Longman Inc.

[2] Cameron, Lyne. 2001. Teaching Languages to Young Learners. Trumpington Street: Cambridge University Press.

[3] Damanik, Juliana. 2009. A Study On English Speaking Diffculty Of The SecondmYear Students At SMA Negeri 2 Sidikalang. Pematangsiantar: Unpublished English Education HKBP Nommensen University Pematangsiantar.

[4] Hughes, Arthur. 2003. Testing for Language Teachers. Camridge: Cambridge University Press.

[5] Keegan, Sheila.2009. Qualitative Research: Good decision through understanding people, cultures and markets. Great Britania: Market Research in Practice.

[6] Luoma, Sari. 2004. Assessing Speaking. New York: Cambridge University Press
[7] Nunan, D. 1991. Research Methods in Language Learning. Cambridge : University Press

[8] Richards, Jack C. 2008. Teaching Listening and Speaking : From theory to Practice. New York: Cambridge University Press

[9] Thornburry, Scott. 2005. How To Teach Speaking. San Fransisco: Longman

[10] Widya, Satya 2012. The use of Role-Play Motivate Students to Speak: A Classroom Experience. Jurnal Humaniora, vol 1, 1-2 